\title{
Banking Sector Operations and Foreign Direct Investment in Nigeria: A Causality Analysis
}

\author{
Patrick Kanayo Adigwe ${ }^{1}$--- Celestine Sunday Okaro ${ }^{2}$--- Ikenna Justin Emejulu ${ }^{3}$--- \\ Amalachukwu Chijindu Ananwude ${ }^{4 *}$ \\ 1,2,3,4Department of Banking and Finance, Nnamdi Azikiwe University, Anambra State, PMB 5025, Awka, \\ Nigeria \\ ${ }^{4}$ Email: amalision4ltd@yahoo.com
}

\begin{abstract}
This study examined the causality relationship between banking sector operations in Nigeria and foreign direct investment from 1997 to 2015. The causal relationship between Foreign Direct Investment (FDI) and banking sector development in Nigeria is not clear yet, while there abounds empirical and theoretical studies on the nexus between foreign direct investment and economy in general, considerable attempts has not been made on the causality relationship between and banking operations in Nigeria. Specifically, this study ascertained the causal relationship between banking sector deposits, loans and advances, foreign exchange transactions, domiciliary operations, international banking operations and foreign direct investment. To achieve these objectives, this study employed Ordinary Least Square (OLS) econometric technique, Auto Regressive Distributive Lag (ARDL) bound test and granger causality test among others. Secondary data were collected from Central Bank of Nigeria statistical bulletin of 2015. The result indicated significant causal bidirectional relationship between banking sector deposits, foreign exchange transactions and foreign direct investments; a significant unidirectional causal relationship between domiciliary operations and foreign direct investment, while no significant causal relationship existed between loans and advances, international banking operations and foreign direct investment. The study recommends that banking sector should adopt completely smart banking as this evidences low risk, reliability and stability of the banking sector which is essential for inflow of foreign direct investments. Central Bank of Nigeria should cautiously focus on tackling monetary policy variables such monetary policy rate, cash reserve ratio and loan portfolio which a capable of attracting investors from abroad.
\end{abstract}

Keywords: Banking operation, Foreign direct investment.

Licensed: This work is licensed under a Creative Commons Attribution 4.o License.

\section{Introduction}

Financial sector foreign direct investments, a relatively new phenomenon, typically takes the form of banks in industrialized countries establishing branches and facilities in developing countries (Goldberg, 2007). The Nigeria law allows inflow of foreign direct investments in the banking sector. Foreign investors or foreign banks are permitted to operate in Nigeria provided they meet the minimum capital requirements and Central Bank of Nigeria regulation in addition to other laws allowing foreign investment in Nigeria. According to the Central Bank of Nigeria Policy on foreign banks' participation in the Nigerian banking system, foreign individuals or institutional investors could also invest in existing Nigerian banks, however, there is a condition that no single foreign individual/institutional investor should acquire more than the share 
of the single largest Nigerian individual/institutional investor in any bank, provided the aggregate shareholding of the foreign investors do not exceed $10 \%$ of the total capital of the bank. The policy guidelines went further to assert that foreign banks could acquire or merge with a local bank existing in Nigeria but, such foreign bank must have operated in Nigeria for at least five years and established branches in at least $2 / 3$ of states of Nigeria (excluding the state capital), provided the foreign bank/investors' shareholding arising from the merger/acquisition should not exceed $40 \%$ of the total capital of the resultant entity.

The banking sector is meritoriously controlled by domestic individual compared to foreigners. The overwhelming ownership by domestic individuals is a function of the outcome of the indigenization programme of 1977 which effectively transferred ownership of banks from foreigners to domestic individuals and institutions (Ani, Odo and Okelue, 2012). However, the reforms at different point in time in the financial system have attracted foreign banks to operate in Nigeria. The two foreign banks operating in Nigeria are Standard Chartered Bank from South Africa and Citi Bank from USA. Standard Chartered Bank and Citi Bank started operations in Nigeria in 1999 and 1984 respectively. As at today, Standard Chartered Bank have about forty (40) branches in Nigeria while Citi Bank has ten (10) branches. Besides, the presence of foreign banks in Nigeria, foreign investors have ownership interest in banks operating in Nigeria. As at 2015, based on banks annual reports and accounts, the percentage of foreign shareholding in some banks operating in the country were value to be $6.39 \%$ for Access Bank Plc, $41.54 \%$ for First City Monument Bank, 14.73\% for First Bank Nigeria Limited, $54.46 \%$ for Stanbic IBTC Bank, $38.81 \%$ for Sterling Bank and $70.44 \%$ for Eco Bank Transnational Plc. Diamond Bank, Fidelity Bank, Guaranty Trust Bank, United Bank for Africa, Unity Bank, Wema Bank and Zenith Bank has no foreign shareholding. Based on the foregoing, this study is set out to examine the causal relationship between banking operations and foreign direct investments in Nigeria's banking sector from 1997 to 2015. Specifically, the causal relationship between banking sector deposits, loans and advances, foreign exchange transactions, domiciliary operations, international banking operation and foreign direct investments

We arranged this study as follows: with the introduction of the study in section one, we proceeded to explaining the major concepts and reviewed relevant literature in section two. In section three, the methodology context was dispelled. Section four discussed the data, sensitivity analysis and regression output interpretation, while conclusion drawn from available data was spell out in section five.

\section{Review of Related Literature \\ 2.1. Clarification of Concepts \\ 2.1.1. Banking Operations}

Banking operations are the legitimate day to day activities carried out by banks such as acceptance of deposits, lending of credits, foreign exchanges provision, etc. Owing to the sensitive nature of the banking sector, banking operations are strictly regulated compared to other sectors of the economy. The noncompliance to approved operations leads to sanction by the Central Bank of Nigeria- the sole regulator of the banking sector, and in some cases, withdrawal of operating license. Banking operation is central to money supply mechanism in an economy as it provides the aggregate credit to the domestic economy as well as international liquidity through net foreign assets both of which are essential variables of money supply (Ngerebo, 2012). The banking sector in Nigeria is one of the major player in the financial system coupled with its critical role in financial intermediation process. Virtually all the funds for productive economic activities are provided by the deposit money banks. The stock market is just the provider of funds to the privileged few who vividly meet requirements for listing. The stock market is completely of the reach of small and medium scale enterprises which are dominance players in economic activities in the country. The banking sector provides relevant financial services such as deposits, loans and advances, foreign exchange operations, domiciliary operations, international banking operations, trusts and information services among others. Notwithstanding the dominance of the banking sector over stock market, the financial services penetration to the populace are still very low compared to some developing countries in Africa like South Africa and other advances countries in the world, due to, but not limited to, changes in government economic policies, instability in macroeconomic fundamentals, operating environment and monetary policies variations.

There are a lot of channels through which foreign direct investment affects banking growth sector growth, however, this study is limited to five selected fundamental via deposits, loans and advances, foreign exchange transactions, domiciliary operations and international banking operations. These fundamentals are succinctly discussed below.

\subsubsection{Deposits}

Past literatures have laid claim that increase inflow of foreign investment causes upsurge in host country's banking sector deposits as foreign direct investment comes with money. Deposits are total funds of individuals, firms, organizations, state and local governments among others in demand, savings, time and other types of accounts operated by banks. The deposits of the banking sector has rising over the years owing to various reforms in the banking system. The total deposits in the banking sector as at 1981 was 10.7 billion, however, the end of 2015, it has tremendously risen to $\$ 29,161.98$ billion, an indication of stability 
and reliability of the banking system. With the exception of the financial crisis that hit the economy in 2009 which depreciated banking sector deposits by $7.80 \%$, the deposits of the banking sector has not witnessed any fluctuation. Okeke (2015) reported that Nigerian banks were much healthier and stronger than in the tumultuous period of the 2008-09 crisis in Nigeria's financial sector as customers withdrew their money and the banks' deposit ratios deteriorated. Within the period of the crisis, the Central Bank of Nigeria injected funds into some banks discovered to have had huge toxic assets in their balance sheet, and some managing directors/CEO were removed and forensic audit of the entire banking sector conducted.

\subsubsection{Loans and Advances}

Increased inflow of foreign capital in the banking sector through foreign ownership would in no small magnitude increase the loans and advances extended to economy for productive activities which ultimately results in growth and development of the economy. Similar to deposits, the loans and advances extended by the banking sector to the economy have also witnessed undeniable appreciation. The sectorial allocation of loans and advances favours the oil and gas sector to other sectors of the economy. The preference of the oil and gas sector is due to the huge nature if their assets and considering the fact that oil is the major source of government revenue. In 2015 , the total credit to the oil and gas sector was $\$ 3,328.58$ billion compared to $\$ 1$, 870.56 billion for manufacturing, $\$ 498.36$ billion for power and energy and $\$ 467.63$ billion for agriculture. To meet with up with growing demand for loan amidst the global financial crisis, the banking sector has to borrowed abroad resulting in increase in their foreign liabilities from $\$ 100.8$ billion in 2007 to $\$ 146.2$ billion in 2010, balances held for other banks outside Nigeria felled to 15.8 billion in 2010 as against $\$ 124.0$ billion in 2007. Following the Sanusi reform that prevailed in the banking sector during the global financial meltdown, stability has returned in the banking system and the capacity to extend credits to the economy boosted. The total credits of the banking sector appreciated to $\$ 13,222.65$ billion in 2015 compared to $\$ 8,912.10$ billion in 2009.

\subsubsection{Foreign Exchange Transactions}

It is the conversion of a country's currency to another for the purpose of transaction executed by the banking sector over a specified period of time. Foreign exchange transactions operations of the banks is the facilitator of international trade between Nigeria and the outside world as it involves the sales and purchase of foreign exchange. As international competitiveness increases, the demand and supply for foreign exchange also increases in the same magnitude, and this increases the volume of foreign exchange transaction which also translates to increase in the volume of banking sector activities as they remain the major player in foreign exchange market (Manyo, Sabina and Ugochukwu, 2016). The proper documentation of foreign exchange transactions in Nigeria for the banking sector following series of foreign exchange regimes in Nigeria based on Central Bank of Nigeria 2015 report, started in 1997. Since then, the banking sector remains an active player in the foreign exchange market. The foreign exchange operations of the banking sector are sectorial divided visa viz: imports and invisibles. Imports include foreign exchange services for agricultural, industrial, finished goods, transport, personal effects, minerals and oil and gas services while invisibles such as education, airlines remittance, estacode, re-insurances and contract services among others are cared for in foreign exchange operations of the banks. The imports constitute $68.99 \%$ of foreign exchange operations of the banking sector while $31.01 \%$ are invisibles.

\subsubsection{Domiciliary Operations}

Domiciliary accounts are banks accounts in foreign currencies such as British Pound, US dollar, Japanese Yen, etc. other than the local currency: Naira for the purpose of international transactions, and maintained by individuals, firms, corporate organization, etc. deposits are made in foreign currency and same applies to withdrawals. The banking sector operated two types of domiciliary accounts: savings and current domiciliary accounts which are equivalent to the savings and current accounts in the local currency. From 1981 till 1993 , there was no domiciliary account operations in the banking sector. However, in 1993, deposit money banks engaged in the financial service of domiciliary account operation. According to the 2015 statistical bulletin of the Central Bank of Nigeria, banking sector domiciliary operations was valued at 1.7 billion. Contemporary, domiciliary operations have vehemently expanded from a value of $\$ 1.7$ billion in 1994 to 4, 357.03 billion in 2015.

\subsubsection{International Banking Operations}

International banking operations refer to the banking activities of the banking sector outside Nigeria. Put differently, there are banking transaction across national boundaries. The banking sector international banking operations cover claims on non-residents banks, balances held with banks, offices and branches, loans and advances, bills discounted payable outside Nigeria, treasury bills of foreign governments, attached assets, international gold tranche, special drawing rights, regional monetary corporation and other foreign assets. The international banking operation of the banking sector was valued at $\$ 0.3$ billion in 1981 but, this has magnificently surged over the years. As at 2015, the international banking operation of the banking sector was 
summed to worth $\$ 1,735.6$ billion. Nigerian banks have expanded operations in some countries in Africa and other countries of the world owing to banking reform of 2004 which increased the minimum capital base for national regional and international banking. For instance, Access Bank Plc operates in Gambia, Burundi, Rwanda, Ghana, London, China and UK among other countries in the globe. The same applies to United Bank for Africa Plc, Zenith Bank International Plc, Union Bank Plc, Skye Bank Plc, First Bank Nigeria Limited, Guaranty Trust Bank, First City Monument Bank and Diamond Bank.

\subsection{Theoretical Buttress}

Many theories have been advanced in connection with foreign direct investments and economic growth as it passes through the financial system. Among these theories are Production Cycle Theory, Eclectic Paradigm Theory, Internationalization Theory and Theory of Exchange rate on imperfect capital market. However, this study discussed briefly two of the theories: Eclectic Paradigm Theory and Endogenous Optimum Currency Area Hypothesis due their closeness in explaining banking sector foreign direct investments. This study is anchored on the Endogenous Optimum Currency Area Hypothesis because offers the closets reason for foreign direct investments in the banking sector.

\subsubsection{Eclectic Paradigm Theory}

The Eclectic Paradigm Theory was introduced by John Dunning in 1973 otherwise called the Dunning OLI's theory because it was modelled from the aspects of other theories. Eclectic paradigm theory of foreign direct investment centres on three factors via ownership, location and internationalization. In the words of Louangrath (2014) if one asks whether all the three factors pass the test in each foreign direct investment case. The answer is no; it might be the case that only one factor is caught in the nest, especially in the banking sector. The ownership factor implies the intangible assets at the possession of a firm which it can, at its discretion, transfer such intangible assets to other firms abroad to earn profit or reduced cost of production usually via contract agreement. The aspect of location come to play depending on transnational country where such intangible assets is highly needed or where the utilization will provide higher returns. However, the choice of location may be hindered by macroeconomic environment, infrastructural potency and political consideration among others. The third factor: internationalization depends on actualization of the assumption/conditions of ownership and location aspects. Internationalization is the various channels available to a company to exercise its control from the sale of its goods or services based on the contract agreement with other companies.

\subsubsection{Endogenous Optimum Currency Area Hypothesis}

According to Mundell who popularised this theory in 1973, barriers to trade lead to increase inflow of foreign direct investment. It is also called the capital market theory of foreign direct investment. The Endogenous Optimum Currency Area Hypothesis assumed that if there is a trade barrier between countries, the ideal option would be to take the bold step and enter the country in focus, then set up business machineries for production and make products or services available for sale. Following Louangrath (2014), Toyota of Japan setting up car production plant in US that produces Lexus cars to bypass US barriers on foreign cars vehemently fit into the Endogenous Optimum Currency Area Hypothesis of Mundell. The same applies to Nissan motors of Japan which also established production plant in the US that produces Infinity cars. Makoni (2015) noted that foreign investment in general arose as a result of capital market imperfections. While this capital market theory holds true in the case of developed countries such as the United States, United Kingdom and Canada, it was challenged by later scholars on the basis of ignoring basic currency risk management fundamentals (Makoni, 2015).

\subsubsection{Justification for Endogenous Optimum Currency Area Hypothesis as Theoretical Underpin}

The banking sector is one of the most regulated sector in Nigeria compared to other sectors because of the critical role of banking operations and the resultant effect on the financial system in general. The strict regulation in the banking sector does not only applies to Nigeria but to other countries especially, developing economies with the aim of guaranteeing sound, reliable and stable financial system capable mobilizing funds needed for growth and development. Foreign direct investment in the banking sector by a single foreign/institutional investor is limited $10 \%$ of a bank total capital. This restriction on foreign ownership in banks have automatically created a barrier to foreign investments in the banking sector compared to, say a country like Thailand that allows $49 \%$ foreign ownership stake. If any single foreign/institutional investor who despite this restriction, acquire an ownership stake of not more than $10 \%$, he/she has indirectly fulfilled/abide by postulation of Endogenous Optimum Currency Area Hypothesis which envisaged that trade barrier increases the inflow of foreign direct investments in host economy. If this study should anchor on the Eclectic Paradigm Theory foreign direct investment by John Dunning based on foreign ownership restriction as applicable in the Nigeria banking sector, then the ownership aspect assumption of Eclectic Paradigm Theory has failed thus favouring Endogenous Optimum Currency Area Hypothesis as the theoretical basis for this study is pursued. 


\subsection{Empirical Review}

Owing to the heavy regulation in the banking sector, empirical studies on foreign direct investments and banking sector operations are few and in most scare particularly, for emerging economies as emphasis are placed on manufacturing through setting up of industries. However, the few available literatures that closely related foreign direct investment in the banking sector were reviewed.

Tajgardoo, Noormohamadi and Behname (2012) studied the causality relationship between FDI and Islamic banking. Panel unit root tests show that the variables are stationary at level. Pedroni test indicates that there is not log run relationship between FDI and Islamic banking. Data chosen 9 countries from Organization Islamic Conference (OIC) over the period 1995-2010 were used for analysis. The results showed that there is a bidirectional relationship between these variables (the feedback relationship). It means that FDI reinforce Islamic banking and Islamic banking attracts foreign direct investment.

O'Connor, Santos-Arteaga and Tavana (2014) proposed a game-theoretical model for commercial bank foreign direct investment strategy, government policy and domestic banking industry interactions in emerging market economies and demonstrate the application of this strategy to the banking system. The paper develops a game-theoretical model to analyse the optimality of the limiting entry strategy followed by a given domestic institutional sector when considering the entry applications of foreign banks in the domestic financial system. The paper showed that the progressive liberalization of entry restrictions would define the perfect Bayesian equilibria of the subsequent set of continuation games and the respective payoffs derived from this liberalization as the domestic economy integrates and competes within the global financial system.

Tsaurai (2014) investigated if there is a causality relationship between banking sector development and FDI inflows in Botswana. Three arguments were raised regarding the relationship between banking sector development and FDI inflows into the host country. The first perspective says that banking sector development attracts FDI inflows into the host country. The second perspective suggests that there is a positive feedback effect between banking sector development and FDI inflows whilst the third perspective maintains that there is no direct causality relationship between the two variables. The results from the study were consistent with the third perspective that says there is no direct causality relationship between banking sector development and FDI net inflows. This confirms that the long run relationship between banking sector development and FDI net inflows is an indirect one and the two set of variables affect each other indirectly through other factors in Botswana.

Poelhekke (2014) hypothesized whether global banks facilitate foreign direct investments. Using a new detailed data set of outward FDI and exploiting heterogeneity in banking sector deregulation across countries and time, the paper found that banks' direct investment abroad increased the volume of non-financial FDI from the same home-market. This effect is stronger in countries where investing is more hazardous, those with worse corruption and rule of law. Importantly, they did not find that host-market domestic or thirdcountry foreign banks facilitate FDI.

Kim (2013) using data collected from 60 countries for the years 1990-2010 examined the relationship between Foreign Direct Investment and a banking crisis in addition to the linkage between a banking crisis and domestic investment. The pooled ordinary least squares was used for the first empirical method. The lagged investment is done for robustness and the fixed effects is used to check a final robustness. The results indicated that banking crisis is highly correlated with domestic investment rate while the lagged value of banking crisis does not seem to have any significant impact. However, the results with fixed effects show that the lagged effect of banking crisis has a large impact on investment while the banking crisis variables turn out to be not correlated with investment. For FDI, both the banking crisis and the lagged value of banking crisis do not show any significance in all specifications.

Onyekwena (2012) investigated the impact of Foreign Direct Investment on Nigerian manufacturing firms and banks. Unique data obtained from a survey of Nigerian firms conducted by the Centre for the Study of African Economies, University of Oxford, and United Nations Industrial Development Organization was employed for the estimations based on manufacturing firms. For the investigation based on Nigerian banks, the study used the BankScope data base. Ordinary Least Squares and Fixed Effects techniques were used to estimate the coefficients of foreign presence measures in augmented Cobb-Douglas models for manufacturing firm data, and augmented Dealership models for data on banks. Results of the estimations show evidence of positive effects of foreign presence on domestic manufacturing firms, while no effects were obtained from the estimations based bank data. The differences in FDI effects reflect on the sector-specific characteristics of manufacturing firms and banks in Nigeria. Manufacturing firms in Nigeria operate at low technology levels and are open to foreign direct investment, while the opposite seems to be case of banks in the country. The results therefore support earlier thoughts in literature on FDI which assert that positive spillovers exist were technology gaps between foreign firms and domestic firms exist, or in sectors open to FDI.

Wezel (2004) assessed the factors crucial in the locational decisions of multinational German banks in selected emerging market of central and Eastern Europe, Latin America and Asia from 1994 to 2001. Emphasis was placed on testing macroeconomic variables and financial risk factors along with measures of bank-client integration and host country market characteristics. Results indicated that FDI by non-bank exerted a strong pull effect on banking FDI inflows. 
Oke (2012) explored the relationship between foreign direct investment and financial sector growth, providing empirical evidence from Nigeria. Annual time-series data were gathered on foreign direct investment, market capitalization, Gross Domestic Product, External Debt, Inflation rate, Exchange Rate and Degree of openness (ratio of imports and exports to gross domestic product) from 1981-2010. The empirical model was analysed using the econometric techniques of ordinary least square method, unit root test, cointegration test, Error correction Mechanism, and Granger causality test. The findings suggested that the inflow of FDI has a positive impact on the Financial Sector in the short run but fail to translate to real long financial sector growth that could promote speedy economic growth due to the fact that the bulk of foreign direct investment has been channelled to other sectors of the economy namely the oil and gas sector.

Adeniyi, Omisakin, Egwaikhide and Oyinlola (2012) examined the causal linkage between foreign direct investment and economic growth in Cotr'd"Ivoire, Gambia, Nigeria and Sierra Leone with financial development accounted for a period 1970 to 2005 within a trivariate framework which applies granger causality tests in VECM setting. Three alternative measures of financial development-total liquid liabilities, total banking sector credit and credit to private sector were employed. The findings supported the view that the extent of financial sophistication matters for the benefits of FDI to register on economic growth in Ghana, Gambia and Sierra Leone. In Nigeria on the other hand, displays no evidence of any short or long run causal relationship from FDI to growth with financial deepening accompanying.

Desbordes and Wei (2013) using a novel database on bilateral real green field manufacturing FDI and two distinct but complementary econometric approaches studies foreign direct investment, financial development and the 2007-2010 global financial crisis. They exploited differences in firm- or sector-specific dependence on external finance and the occurrence of the 2007-2010 banking crises in developed countries. The main results are that source countries' financial development (FD) tends to contribute strongly to the promotion of FDI, especially in sectors typically dependent on external finance, whereas destination countries' FD matter much less and may, in sectors not typically dependent on external finance, even have a negative impact on FDI. Using a panel dataset of bilateral flows of banking sector foreign direct investment (FDI) in developed and developing countries, we study the impact of regional integration agreements (RIAs) on the location of banking sector FDI.

Laifi (2008) ascertained whether regional integration agreement matters in FDI attraction in the banking sector. The results indicated that the impact of RIAs vary depending on different kinds of regional integration. Hope, Laurenceson and Qin (2008) analysed the impact of foreign participation on Chinese banking by studying its different manifestations in China's commercial banks. They found that strategic investors play an important role when stated owned commercial banks (SCBs) and other shareholding banks start their IPO processes, either abroad or in the local market. Data show that most banks entering partnerships with foreign interests derive "direct benefits:" they improve their capability for financial innovation - in structural reorganization, and new products and services -- by this transfer of management knowledge from their foreign partners.

Asante (2015) examined the impact of foreign direct investment on the performance of the banking sector of Ghana. To accomplish this objective, the study used panel data for sixteen (16) financial institutions (universa 1 banks) from the year 2000 to 2012. Random effect models were estimated and the results suggested that Foreign Direct Investment inflows into the country positively and significantly impact on banks' capital stock. The results also suggest that, FDI positive and significant impact on the liquidity position of financial institutions in Ghana. However, the study found a negative and insignificant relation between FDI and banks' profitability.

Korna, Ajekwe and Idyu (2013) studied the level of impact; foreign direct investment has on the Nigerian banking sector in the wake of the unprecedented capital flight from the Nigerian economy during the recent global economic recession (the credit crunch). Data which are secondary data nature were obtained from statistical bulletins of the Central Bank of Nigeria. The expost-facto research design was adopted to determine the level of the impact for 25 deposit money banks for the period 2006-2010. The ordinary least square (OLS) estimation technique was employed and the results revealed that there is a non-positive significant impact of foreign direct investment on the equity capital of the Nigerian banking sector, there is a negative insignificant impact of foreign direct investment on the liquidity position of the Nigerian banking sector and there is a negative insignificant impact of foreign direct investment on the total assets of the Nigerian banking sector.

\section{Data and Method}

A test of causation was utilized in determining the causal relationship between foreign direct investments and banking operations using yearly data from the Central Bank of Nigeria (CBN) statistical bulletin of 2015. Foreign Direct Investments is the dependent variable and was symbolized by (FDI). The independent variables are the surrogates of banking sector operations which include: Total Deposits (TDP) in the banking sector, Loans and Advances (LAD), Foreign Exchange Transactions (FET), Domiciliary Operations (DOMP) and International Banking Operations (IBKP). 


\subsection{Model Estimation}

This study adopted a modified model of Tajigardon, Noormohamadi and Behname (2012) for a study in nine selected countries from Organisation Islamic Conference (OIC): Bahrain, Iran, Malaysia, United Arab Emirates, Pakistan, Kuwait, Saudi Arabia, Qatar and Turkey. The researcher expressed foreign direct investments as a function of Islamic banks assets, the original model thus:

$$
\begin{aligned}
& F D I_{i t}=a_{1 t}+\varphi_{1 t} F D I_{i(t-1)}+\varphi_{2 t} F D I_{i(t-2)}+\beta_{1} I B A_{i(t-1)}+\beta_{2} I B A_{i(t-2)}
\end{aligned}
$$

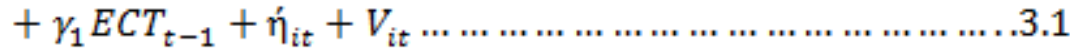

Where $F D I$ is foreign direct investment, $I B A$ is ratio of Islamic banks assets divided by Central Bank assets plus Islamic banks assets, $a_{1 t}$ captures time effect and $\eta_{i t}$ captures individual effect.

To determine the causal relationship between foreign direct investments and banking operations variables: total deposits, loans and advances, foreign exchange transactions, domiciliary operations and international banking operation, the following models in functional form were estimated:

$F D I=f(T D P)$
$F D I=\ldots \ldots n$

To avoid the possible effect of any outlier that may cast a dent on the result of analysis or result in nonnormality distribution of variables, the models were transformed in log-linear format as follows:

Model 1

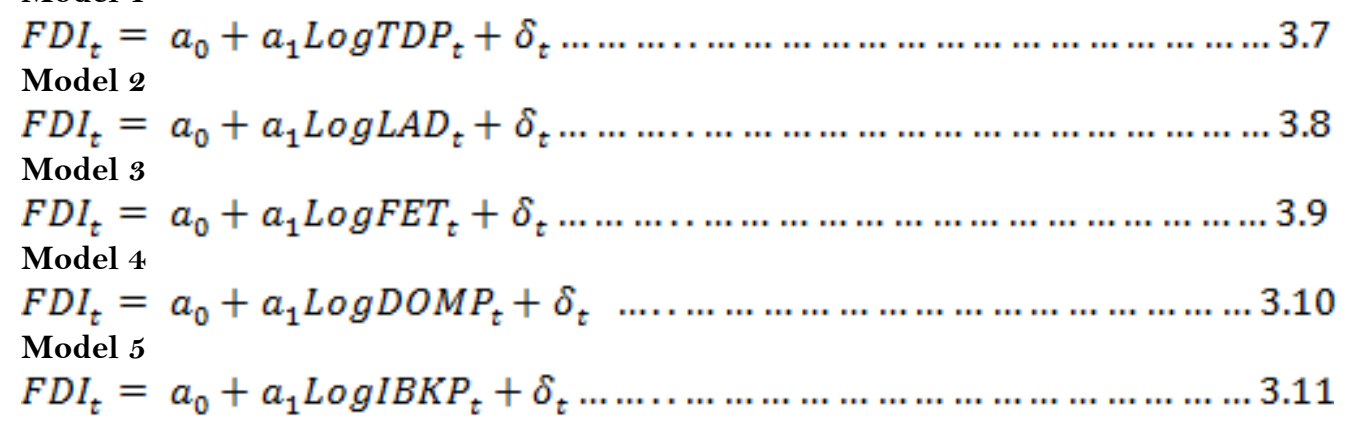

\subsection{Variables Explanation}

FDI is foreign direct investments: This are the investments made by foreign investors in the form of either setting up a business enterprise or having controlling right or ownership privilege in business enterprise in Nigeria. In financial account section of the balance of payment statement, it is the liability of Nigeria to other countries of the world. Foreign direct investment was utilized in the works of Tajigardon, Noormohamadi and Behname (2012) and O'Connor, Santos-Arteaga and Tavana (2013).

TDD is total deposits of the banking sector: In this study, total deposit are the funds of private sector, state and local government in different account types operated by the banks that can be withdrawn anytime. Total deposit encompasses demand, savings and time deposits in the banking sector. To the banks, deposits are short term, medium or long term obligation to customers.

LAD is the total loan and advances of the banking sector: This is the credit the banking sector extends private sector, state and local government. Put differently, it is total credit the banks extends to the economy productive economic activities, services, etc.

FET is foreign exchange transactions: Foreign exchange transaction details the sales and purchase of foreign currencies for international trade and other services outside a country. The foreign exchange transaction as applied in this research work encompass the total foreign exchange provided by the banking sector and utilized for transactions valid for foreign exchange.

DOMP is domiciliary operations: This is the foreign currency deposits of private sector, federal, state and local governments in domiciliary accounts of deposit money banks in Nigeria. It is foreign currency liability of the banking sector.

IBKP is international banking operations: International banking operation as used in this research work are monetary value of banking sector operations outside Nigeria. They include bill discounted payable, claims on non-resident banks, balances held with banks, balances held with offices and branches, loans and advances outside Nigeria. 


\section{Result and Discussion of Data Estimations}

\subsection{Summary of Data Descriptive Properties}

Table 1 shows the summary of the descriptive properties of the variables estimated. The summary of the descriptive statistics shows the mean, median, maximum, minimum, standard deviation, skewness, kurtosis, Jarque-Bera, p-value and number of observations. As can be seen in Table 1, the mean of variables were 586442, 2352896, 4729901, 26132.6, 1140292 and 977893 for FDI, TDP, LAD, FET, DOMP and IBKP while $624500,1497900,2524300,18678.9,302400$ and 930700 entails the median respectively for FDI, TDP, LAD, FET, DOMP and IBKP. The maximum and minimum values were 1360300 and 80700 for FDI, 5436000 and 128200 for TDP, 13222650 and 272900 for LAD, 65990.4 and 4783.0 for FET, 4357025 and 5500 for DOMP and 977893 and 930700 for IBKP. The standard deviation discloses 424775.5 for FDI, 2105019 for TDP, 4349060 for LAD, 19217.39 for FET, 1442967 for DOMP and 743478.0 for IBKP. The variables were positively skewed towards normality. As depicted by the Kurtosis, the variables are by nature not leptokurtic.

Table-1. Summary of Descriptive Statistics.

\begin{tabular}{|c|c|c|c|c|c|c|c|c|c|c|}
\hline & Mean & Median & Maximum & Minimum & Std. Dev. & Skewness & Kurtosis & $\begin{array}{l}\text { Jarque- } \\
\text { Bera }\end{array}$ & P-value & Obs \\
\hline$\overline{\text { FDI }}$ & 586442 & 624500 & 1360300 & 80700 & 424775.5 & 0.283734 & 1.817577 & 1.361780 & 0.506166 & 19 \\
\hline TDP & 2352896 & 1497900 & 5436000 & 128200 & 2105019 & 0.351700 & 1.434011 & 2.333114 & 0.311440 & 19 \\
\hline LAD & 4729901 & 2524300 & 13222650 & 272900 & 4349060 & 0.484063 & 1.791750 & 1.897742 & 0.387180 & 19 \\
\hline FET & 26132.6 & 18678.9 & 65990.40 & 4783.00 & 19217.39 & 0.537186 & 1.993545 & 1.715721 & 0.424068 & 19 \\
\hline DOMP & 1140292 & 302400. & 4357025 & 5500.00 & 14429670 & 1.089136 & 2.773449 & 3.796989 & 0.149794 & 19 \\
\hline IBKP & 977893 & 930700 & 2132175 & 53300.00 & 743478.0 & 0.222246 & 1.539981 & 1.843973 & 0.397730 & 19 \\
\hline
\end{tabular}

Source: Output Data from E-views 9.0.

Table-2. Lilliefors Test of Normality.

\begin{tabular}{l|l|l}
\hline Variables & Lilliefors Test Statistic & P-value \\
\hline FDI & 0.201076 & 0.04 \\
\hline TDP & 0.221639 & 0.01 \\
\hline LAD & 0.220289 & 0.02 \\
\hline FET & 0.194852 & 0.05 \\
\hline DOMP & 0.2567180 & 0.00 \\
\hline IBKP & 0.221596 & 0.02
\end{tabular}

The p-value of the Jarque-Bera statistic in Table 1 entails that all the variables were not normally distributed. To this effect and having obtain the mean and standard deviation of the variables, the Lilliefors test of normality was applied to further ascertain the distribution of the variables and result presented in Table 2. The Lilliefors test of normality, which is advancement on the Kolomogorov-Smirnov (K-S) test-correcting the K-S for small values at the tail of probability distribution confirmed that all the variables were normally distributed and does not have any outlier that may results in bias in the regression outcome.

\subsection{Preliminary Test}

Preliminary Analysis of the data via serial LM test, heteroskedasticity and Ramsey reset specification were performed in line with econometric assumption and results summarized in Tables $3-5$. This is to ensure that the model estimated have no problem associated with heteroskedasticity, serial correlation and Ramsey specification. Serial correlation LM test is dispelled in Table 3, heteroskedasticity in Table 4, while Ramsey reset specification in Table 5 .

\begin{tabular}{l|l|l}
\multicolumn{2}{c}{ Table-3. Breusch-Godfrey Serial Correlation LM Test. } \\
\hline Models & F-statistic & P-value \\
\hline Model 1 & 1.247085 & 0.3010 \\
\hline Model 2 & 0.012605 & 0.9160 \\
\hline Model 3 & 2.288013 & 0.1811 \\
\hline Model 4 & 0.237596 & 0.6432 \\
\hline Model 5 & 0.580704 & 0.4749 \\
\hline Source: Data output via E-views 9.0.
\end{tabular}

Table-4. Harvey Heteroskedasticity test.

\begin{tabular}{l|l|l}
\hline Models & F-statistic & P-value \\
\hline Model 1 & 1.546456 & 0.2772 \\
\hline Model 2 & 1.127018 & 0.4726 \\
\hline Model 3 & 0.279738 & 0.9427 \\
\hline Model 4 & 0.944036 & 0.5293 \\
\hline Model 5 & 0.552241 & 0.7742 \\
\hline Source: Data output via E-views 9.0.
\end{tabular}


Table-5. Ramsey Reset Specification test.

\begin{tabular}{l|l|l|c}
\hline Models & F-statistic & df & p-value \\
\hline Model 1 & 0.148775 & $(1,7)$ & 0.7112 \\
\hline Model 2 & 0.149132 & $(1,4)$ & 0.7190 \\
\hline Model 3 & 0.032834 & $(1,6)$ & 0.8622 \\
\hline Model 4 & 1.067699 & $(1,6)$ & 0.3413 \\
\hline Model 5 & 0.438683 & $(1,6)$ & 0.5324 \\
\hline
\end{tabular}

Source: Data output via E-views 9.0.

\subsection{Unit Root Test Result}

The variables were cleaned of stationarity defect that may impede inferences from results of analysis using the Augmented Dickey-Fuller (ADF), Phillips Perron (PP) and Kwiatkowski-Phillips-Schmidt-Shin (KPSS). The unit root test of ADF and PP were performed at level and first difference and three parapets: intercept, trend and intercept and none while KPSS was performed at level and first difference and two parapets: intercept, trend and intercept. Tables 6 and 7 present the ADF test as level and first difference: intercept, trend and intercept. The PP test at level and first difference were summarized in Tables 8 and 9 whereas, Tables 10 and 11 detail the KPPS test at level and first difference in three sets: intercept, trend and intercept and none.

\subsubsection{Augmented Dickey-Fuller (ADF)}

As can be seen in Table 6, all the variables were not stationary at level thus the need for first difference. The first difference ADF test as condensed in Table 7 depicts that the variables were all stationary at the three estimation was effected.

Table-6. Result of ADF Test at Level.

\begin{tabular}{l|l|l|l|l}
\hline Variables & Intercept & Trend and Intercept & None & Remark \\
\hline FDI & $-1.369726(0.57)$ & $-1.107371(0.89)$ & $-0.354609(0.54)$ & Not Stationary \\
\hline TDP & $0.275598(0.96)$ & $-2.064448(0.52)$ & $2.245654(0.99)$ & Not Stationary \\
\hline LAD & $1.195632(0.99)$ & $-3.043118(0.15)$ & $2.542564(0.99)$ & Not Stationary \\
\hline FET & $0.154252(0.95)$ & $-3.639597(0.05)^{*} *$ & $1.801511(0.97)$ & Stationary \\
\hline DOMP & $4.510935(1.00)$ & $1.058447(0.99)$ & $6.728763(0.10)$ & Not Stationary \\
\hline IBKP & $-0.556207(0.86)$ & $-3.834645(0.03)^{* *}$ & $1.254026(0.94)$ & Stationary \\
\hline
\end{tabular}

Source: Data output via E-views 9.0.

Note: The optimal lag for ADF test is selected based on the Akaike Info Criteria (AIC), p-values are in parentheses where $(*)$ and $(* *)$ denote significance at $1 \%$ and $5 \%$ respectively.

Table-7. Result of ADF Test at First Difference.

\begin{tabular}{|c|c|c|c|c|}
\hline Variables & Intercept & Trend and Intercept & None & Remark \\
\hline FDI & $-5.094248(0.00)^{*}$ & $-3.440724(0.02)^{* * *}$ & $-5.1113650 .00)^{*}$ & Stationary \\
\hline TDP & $-3.475949(0.02)^{*} * *$ & $-3.385869(0.04)^{* * *}$ & $-2.495405(0.01)^{*}$ & Stationary \\
\hline LAD & $-3.776471(0.01)^{*}$ & $-4.437350(0.01)^{*}$ & $-0.523367(0.05)^{*} *$ & Stationary \\
\hline FET & $-5.020553(0.00)^{*}$ & $-3.092641(0.01)^{*}$ & $-4.466161(0.00)^{*}$ & Stationary \\
\hline DOMP & $-3.503700(0.03)^{* * *}$ & $-4.173875(0.02)^{* * *}$ & $-2.422262(0.03)^{*} *$ & Stationary \\
\hline IBKP & $-6.609190(0.00)^{*}$ & $-6.331161(0.00)^{*}$ & $-5.563022(0.00)^{*}$ & Stationary \\
\hline
\end{tabular}

\subsubsection{Phillips Perron (PP) Test}

The result of the Phillips Perron (PP) unit root test in Tables 8 is similar to the ADF test in Tables 6 as all the variables were found to be non-stationary. Consequently, the first difference test was conducted which affirmed the stationarity of all the variables at order one 1(1) as enshrined in Table 9.

Table-8. Result of PP Test at Level.

\begin{tabular}{|c|c|c|c|c|}
\hline Variables & Intercept & Trend and Intercept & None & Remark \\
\hline FDI & $-1.301638(0.60)$ & $-1.122965(0.89)$ & $-0.301879(0.56)$ & Not Stationary \\
\hline TDP & $0.228217(0.96)$ & $-2.064763(0.52)$ & $2.010187(0.98)$ & Not Stationary \\
\hline LAD & $0.741168(0.98)$ & $-1.854213(0.63)$ & $2.950667(0.99)$ & Not Stationary \\
\hline FET & $-1.046224(0.72)$ & $-3.570194(0.06)$ & $0.176031(0.72)$ & Not Stationary \\
\hline DOMP & $4.221902(1.00)$ & $1.293148(0.99)$ & $6.728763(1.00)$ & Not Stationary \\
\hline IBKP & $-0.876423(0.77)$ & $-3.834645(0.0)^{* *}$ & $0.639342(0.85)$ & Stationary \\
\hline
\end{tabular}


Table-9. Result of PP Test at First Difference.

\begin{tabular}{l|l|l|l|l}
\hline Variables & Intercept & Trend and Intercept & None & Remark \\
\hline FDI & $-5.018450(\mathrm{O} .00)^{*}$ & $-5.360473(\mathrm{O} .00)^{*}$ & $-5.024417(\mathrm{O} .00)^{*}$ & Stationary \\
\hline TDP & $-3.463545(\mathrm{O} .02)^{* *}$ & $-3.361929(\mathrm{O} .02)^{*}$ & $-2.409524(0.01)^{*}$ & Stationary \\
\hline LAD & $-2.062961(\mathrm{O} .05)^{* *}$ & $-2.240121(\mathrm{O} .04)^{* *}$ & $-2.579283(0.03)^{* *}$ & Stationary \\
\hline FET & $-7.687628(0.00)^{*}$ & $-6.747777(\mathrm{O} .00)^{*}$ & $-4.458500(0.00)^{*}$ & Stationary \\
\hline DOMP & $-3.282087(0.02)^{*}$ & $-4.281323(0.01)^{*}$ & $-2.690806(0.03)^{* *}$ & Stationary \\
\hline IBKP & $-6.826198(0.00)^{*}$ & $-6.513785(0.00)^{*}$ & $-5.409914(0.00)^{*}$ & Stationary \\
\hline
\end{tabular}

Source: Data output via E-views 9.0.

Note: In determining the truncation lag for PP test, the spectral estimation method selected is Bartlett kernel and Newey-West method for Bandwidth, p-values are in parentheses where $\left({ }^{*}\right)$ and $(* *)$ denote significance at $1 \%$ and $5 \%$ respectively.

\subsubsection{Kwiatkowski-Phillips-Schmidt-Shin (KPSS) Test}

From Table 10, the KPSS results reveal that stationarity was attained for all the variables hence, Table 11 which confirmed the non-stationarity of the data at first difference.

Table-10. Result of KPSS Test at Level.

\begin{tabular}{l|l|l|l}
\hline Variables & Intercept & Trend and Intercept & Remark \\
\hline FDI & $0.447413(\mathrm{O} .00)^{*}$ & $0.124001(\mathrm{O} .00)^{*}$ & Stationary \\
\hline TDP & $0.147316(\mathrm{O} .00)^{*}$ & $0.147316(\mathrm{O} .00)^{*}$ & Stationary \\
\hline LAD & $0.564478(\mathrm{O} .00)^{*}$ & $0.128589(\mathrm{O} .00)^{*}$ & Stationary \\
\hline FET & $0.550867(\mathrm{O} .00)^{*}$ & $0.116738(\mathrm{O} .00)^{*}$ & Stationary \\
\hline DOMP & $0.517106(0.02)^{* *}$ & $0.163957(\mathrm{O} .02)^{* *}$ & Stationary \\
\hline IBKP & $0.558389(0.00)^{*}$ & $0.090017(\mathrm{O} .00)^{*}$ & Stationary \\
\hline
\end{tabular}

Source: Data output via E-views 9.0.

Note: The spectral estimation method selected for KPSS test is Bartlett kernel and Newey-West method for Bandwidth, p-values are in parentheses where $\left(^{*}\right)$ and $(* *)$ denotes significance at $1 \%$ and $5 \%$ respectively.

Table-11. Result of KPSS Test at First Difference.

\begin{tabular}{l|l|l|l}
\hline Variables & Intercept & Trend and Intercept & Remark \\
\hline FDI & $0.166038(0.38)$ & $0.261180(0.68)$ & Not Stationary \\
\hline TDP & $0.238368(0.00)^{*}$ & $0.140987(0.38)$ & Stationary \\
\hline LAD & $0.362011(0.00)^{*}$ & $0.054791(0.05)^{* *}$ & Stationary \\
\hline FET & $0.431323(0.38)$ & $0.500000(0.85)$ & Not Stationary \\
\hline DOMP & $0.606919(0.00)^{*}$ & $0.155838(0.00)^{*}$ & Stationary \\
\hline IBKP & $0.054296(0.22)$ & $0.053407(0.86)$ & Not Stationary \\
\hline
\end{tabular}

Source: Data output via E-views 9.0.

Note: The spectral estimation method selected for KPSS test is Bartlett kernel and Newey-West method for Bandwidth, p-values are in parentheses where $(*)$ and $(* *)$ denotes significance at $1 \%$ and $5 \%$ respectively.

\subsection{Dependability of Long Run Relationship}

Prior to estimating the long run relationship between foreign direct investments and banking operation, it is ideal to ascertain the reliability of this relationship. With regard to this, the VAR lag order selection criteria was estimated to determine the lag length. The optimal lag level are evaluated with the aid of Akaike information criterion (AIC) and Schwarz information criterion (SC) test statistics. In VAR estimation technique, the reliability of a model is dependent on a low Akaike information criterion (AIC) and Schwarz information criterion (SC) values. Tables 12 - 16 summarize the VAR lag order selection criteria which the lag lengths were automatically selected by econometric software: e-views 9.0.

\begin{tabular}{|c|c|c|c|c|c|c|}
\hline Lag & $\log L$ & LR & FPE & AIC & SC & HQ \\
\hline $\mathrm{O}$ & -535.8269 & $\mathrm{NA}$ & $3.08 \mathrm{e}+23$ & 59.75855 & 59.85748 & 59.77219 \\
\hline 1 & -499.5433 & $60.47269^{*}$ & $8.57 \mathrm{e}+21 *$ & $56.17148 *$ & $56.46827 *$ & 56.21240* \\
\hline
\end{tabular}

Table-13. Lag Length Criteria for FDI and LAD.

\begin{tabular}{l|l|l|l|l|l|c}
\hline Lag & LogL & LR & FPE & AIC & SC & HQ \\
\hline 0 & -551.1735 & NA & $1.69 \mathrm{e}+24$ & 61.46372 & 61.56265 & 61.47737 \\
\hline 1 & -518.6129 & $54.26772 *$ & $7.13 \mathrm{e}+22^{*}$ & $58.29032^{*}$ & $58.58711^{*}$ & $58.33124 *$ \\
\hline
\end{tabular}
\%ource: Data output via E-views 9.0.
error, AIC: Ak Akaike information criterion, SC: Schwarz information criterion and HQ: HannanQuinn information criterion.


Table-14. Lag Length Criteria for FDI and FET.

\begin{tabular}{l|l|l|l|l|l|l}
\hline Lag & LogL & LR & FPE & AIC & SC & HQ \\
\hline 0 & -452.6207 & NA & $2.97 \mathrm{e}+19$ & 50.51342 & 50.61235 & 50.52706 \\
\hline 1 & -433.4116 & $32.01521^{*}$ & $5.52 \mathrm{e}+18^{*}$ & $48.82351^{*}$ & $49.12030^{*}$ & $48.86444^{*}$ \\
\hline
\end{tabular}

* Indicion error, AIC: Akaike information criterion, SC: Schwarz information criterion and HQ: HannanQuinn information criterion.

Table-15. Lag Length Criteria for FDI and DOMP.

\begin{tabular}{l|l|l|l|l|l|l}
\hline Lag & LogL & LR & FPE & AIC & SC & HQ \\
\hline 0 & -535.3386 & NA & $2.91 \mathrm{e}+23$ & 59.70429 & 59.80322 & 59.71793 \\
\hline 1 & -481.2051 & $90.22254^{*}$ & $1.12 \mathrm{e}+21^{*}$ & $54.13390^{*}$ & $54.43069^{*}$ & $54.17483^{*}$ \\
\hline
\end{tabular}

Source: Data output via E-views 9.0.

* Indicates lag order selected by the criterion, LR: sequential modified LR test statistic (each test at $5 \%$ level), FPE: Final prediction error, AIC: Akaike information criterion, SC: Schwarz information criterion and HQ: HannanQuinn information criterion.

Table-16. Lag Length Criteria for RGDPGR and IBKP.

\begin{tabular}{l|l|l|l|l|l|l}
\hline Lag & LogL & LR & FPE & AIC & SC & HQ \\
\hline 0 & -517.0209 & NA & $3.81 \mathrm{e}+22$ & 57.66899 & 57.76792 & 57.68263 \\
\hline 1 & -493.5491 & $39.11955^{*}$ & $4.40 \mathrm{e}+21^{*}$ & $55.50546^{*}$ & $55.80225^{*}$ & $55.54638^{*}$ \\
\hline
\end{tabular}

Source: Data output via E-views 9.0

* Indicates lag order selected by the criterion, LR: sequential modified LR test statistic (each test at $5 \%$ level), FPE: Final prediction error, AIC: Akaike information criterion, SC: Schwarz information criterion and HQ: HannanQuinn information criterion.

\subsection{Co-integration Relationship}

The long run relationship was estimated with the aid of Johansen co-integration and Auto-Regressive Distribute Lag (ARDL) model techniques. The result of the ARDL long run relationship between foreign direct investments and banking operations indices as presented in Tables $17-21$ reveal the presence of a long run relationship between foreign direct investments, total deposits and foreign exchange transactions of the banking sector. The F-statistic values of 6.24, 16.39 and 13.53 for total deposits, loans and advances and foreign exchange transactions of the banking sector respectively are greater than the lower and upper bound test statistic of 4.94 and 5.73 sequentially at $5 \%$ level of significance.

Table-17. Bound Test for FDI and TDP.

\begin{tabular}{l|l|l|l}
\hline T-Test & 5\% Critical Value Bound & Remark \\
\hline F-Statistic & Lower Bound & Upper Bound & \\
\hline 6.241097 & 4.94 & 5.73 & Null Hypothesis Rejected \\
\hline \multicolumn{2}{l}{ Source: Data output via E-views 9.0. }
\end{tabular}

Table-18. Bound Test for FDI and LAD.

\begin{tabular}{|c|c|c|c|}
\hline T-Test & \multicolumn{2}{|c|}{$5 \%$ Critical Value Bound } & Remark \\
\hline F-Statistic & Lower Bound & Upper Bound & \\
\hline 16.38591 & 4.94 & 5.73 & Null Hypothesis Rejected \\
\hline
\end{tabular}

Table-19. Bound Test for FDI and FET.

\begin{tabular}{l|l|l|l}
\hline T-Test & \multicolumn{2}{|c|}{ 5\% Critical Value Bound } & Remark \\
\hline F-Statistic & Lower Bound & Upper Bound & \\
\hline 13.533234 & 4.94 & 5.73 & Null Hypothesis Rejected \\
\hline Source: Data output via E-views 9.0
\end{tabular}

Table-20. Bound Test for FDI and DOMP.

\begin{tabular}{l|l|l|l}
\hline \multicolumn{3}{c}{ Table-20. Bound Test for FDI and DOMP. } & Remark \\
\hline F-Statistic & Lower Bound & Upper Bound & \\
\hline 3.008311 & 4.94 & 5.73 & Null Hypothesis Accepted \\
\hline
\end{tabular}

Table-2 1. Bound Test for FDI and IBKP.

\begin{tabular}{|c|c|c|c|}
\hline T-Test & \multicolumn{2}{|c|}{$5 \%$ Critical Value Bound } & Remark \\
\hline F-Statistic & Lower Bound & Upper Bound & \\
\hline 2.841479 & 4.94 & 5.73 & Null Hypothesis Accepted \\
\hline
\end{tabular}




\subsection{OLS Regression Results}

The short run relationship for the subject matter was ascertained through the OLS methodology and the results presented in Tables 22 - 26. The interpretations were anchored on the global and relative statistics of the variables. From Table 22, there is a positive and significant relationship between foreign direct investments and total deposits. The coefficient of the constant 173607.6 implies that total deposits foreign direct investments would be $\$ 173,607.6$ million. As shown by the total deposits coefficient of 0.387442 , a unit increase in total deposits of the banking sector results in $\$ 0.38$ million increase in foreign direct investments. From the Adjusted R-squared, 65.39\% variation in foreign direct investments was explained by changes in total deposits of the banking sector. The p-value of the F-statistic unveils that total deposit of the banking sector significantly explained the variation in foreign direct investments within the period studied. Durbin Watson of 1.31 is not that quite close to the bench mark of 2.0. Nevertheless, the deficiency that may be associated this was corrected by the serial correlation test in Table 3 which affirms that the variables in the model are not serially correlated.

Table-22. OLS Regression Result for FDI and TDP.

\begin{tabular}{l|l|l|l|l}
\hline Variable & Coefficient & Std. Error & t-Statistic & Prob. \\
\hline C & $\mathbf{1 7 3 6 0 7 . 6}$ & 95312.09 & $\mathbf{1 . 8 2 1 4 6 5}$ & 0.0885 \\
\hline TDP & 0.387442 & 0.146526 & 2.644190 & 0.0184 \\
\hline TDP $(-1)$ & -0.238457 & 0.151495 & -1.574026 & 0.1363 \\
\hline R-squared & $\mathbf{0 . 6 9 4 6 7 7}$ & Mean dependent var & $\mathbf{6 1 2 8 8 3 . 3}$ \\
\hline Adjusted R-squared & 0.653967 & S.D. dependent var & 420693.4 \\
\hline S.E. of regression & $\mathbf{2 4 7 4 7 1 . 2}$ & Akaike info criterion & $\mathbf{2 7 . 8 2 6 9 9}$ \\
\hline Sum squared resid & $9.19 E+11$ & Schwarz criterion & 27.97538 \\
\hline Log likelihood & $\mathbf{- 2 4 7 . 4 4 2 9}$ & L Hannan-Quinn criter. & $\mathbf{2 7 . 8 4 7 4 5}$ \\
\hline F-statistic & 17.06411 & Durbin-Watson stat & 1.319426 \\
\hline Prob (F-statistic) & $\mathbf{0 . 0 0 0 1 3 7}$ & &
\end{tabular}

As can been seen in Table 23, loans and advances extended to the economy by the banking sector has a positive and significant relationship with foreign direct investments. Looking at the constant coefficient of 319874.2 , if loans and advances of the banking sector is kept constant, foreign direct investments would be $\$ 319,874.2$ million. Similarly, a percentage rise in loans and advances of the banking sector leads be 0.11 million increase in foreign direct investments. Only $47.96 \%$ changes in foreign direct investments that was attributed to variation in loans and advances of the banking sector. The adjusted R-square discloses that loans and advances of the banking sector significantly accounted for the variation in foreign direct investments. The Durbin Watson value of 1.12 does not portray any danger of autocorrelation based on the affirmation from Table 3 that the variable are free from serial correlation.

Table-23. OLS Regression Result for FDI and LAD.

\begin{tabular}{l|l|l|l|l}
\hline \multicolumn{5}{c}{ Table-23. OLS Regression Result for FDI and LAD. } \\
\hline Variable & Coefficient & Std. Error & t-Statistic & Prob. \\
\hline C & 319874.2 & 139414.4 & 2.294413 & 0.0424 \\
\hline LAD & 0.114601 & 0.032298 & 3.548246 & 0.0046 \\
\hline LAD (-5) & -0.098365 & 0.042259 & -2.327677 & 0.0400 \\
\hline R-squared & 0.559665 & Mean dependent var & 757857.1 \\
\hline Adjusted R-squared & 0.479604 & S.D. dependent var & 359808.0 \\
\hline S.E. of regression & 259560.0 & Akaike info criterion & 27.95877 \\
\hline Sum squared resid & $7.41 \mathrm{E}+11$ & Schwarz criterion & 28.09571 \\
\hline Log likelihood & -192.7114 & L Hannan-Quinn criter. & 27.94610 \\
\hline F-statistic & 6.990489 & Durbin-Watson stat & 1.125897 \\
\hline Prob (F-statistic) & 0.010985 & &
\end{tabular}

The regression result in Table 24 shows that foreign exchange transactions of the banking sector has a significant and positive relationship with foreign direct investments. The coefficient of the constant depicts foreign direct investment to be 314,949.5 million when foreign exchange transactions of the banking sector is held constant. A unit appreciation in foreign exchange transactions entails a $\$ 19.71$ million upsurge in foreign direct investments. Considering the adjusted R-square coefficient, $36.07 \%$ variation in foreign exchange transactions was owed to volatility in banking sector foreign exchange transactions. Foreign exchange transactions was significantly responsible for variation in foreign exchange transactions as evidence by p-value of the F-statistics which is significant at $5 \%$ level of significance. There is no problem of autocorrelation in the model even though the Durbin Watson value is 1.31 . This study hinged on the serial 
correlation test in Table 3 which clears the model of serial correlation. Furthermore, the serial correlation LM test is superior to Durbin Watson in testing autocorrelation in a model.

Table-24. OLS Regression Result for FDI and FET

\begin{tabular}{l|c|l|l|l}
\hline Variable & Coefficient & Std. Error & t-Statistic & Prob. \\
\hline C & 314949.5 & 168077.3 & 1.873838 & 0.0877 \\
\hline FET & 19.70869 & 7.540493 & 2.613714 & 0.0241 \\
\hline FET (-5) & -11.88926 & 10.24660 & -1.160313 & 0.2705 \\
\hline R-squared & 0.459079 & Mean dependent var & 757857.1 \\
\hline Adjusted R-squared & 0.360730 & S.D. dependent var & 359808.0 \\
\hline S.E. of regression & 287682.2 & Akaike info criterion & 28.16451 \\
\hline Sum squared resid & $9.10 \mathrm{E}+11$ & Schwarz criterion & 28.30145 \\
\hline Log likelihood & -194.1516 & L Hannan-Quinn criter. & 28.15183 \\
\hline F-statistic & 4.667847 & Durbin-Watson stat & 1.318624 \\
\hline Prob (F-statistic) & 0.034059 & \multicolumn{3}{l}{}
\end{tabular}

The regression output in Table 25 lays credence to the presence of a positive significant relationship between foreign direct investments and domiciliary operations of the banking sector. The constant coefficient of 431867.4 is an indication that foreign direct investments will experience 431 , 867.4 million in growth if domiciliary operations of the banking sector is kept constant. Each time domiciliary operations increases by a unit, foreign direct investments will rise by $¥ 0.58$ million. The revelation from the adjusted R-square shows that domiciliary operations of the banking sector accounted for $60.72 \%$ changes in foreign direct investments, and this is statistically significant based on the 0.00 p-value of F-statistic. The Durbin Watson value of 1.65 is within the acceptable range of no autocorrelation in the model.

Table-25. OLS Regression Result for FDI and DOMP.

\begin{tabular}{l|c|l|l|l}
\hline Variable & Coefficient & Std. Error & t-Statistic & Prob. \\
\hline C & 431867.4 & 98614.69 & 4.379341 & 0.0011 \\
\hline DOMP & 0.584285 & 0.125749 & 4.646428 & 0.0007 \\
\hline DOMP (-5) & -1.490119 & 0.359545 & -4.144452 & 0.0016 \\
\hline R-squared & 0.667663 & Mean dependent var & 757857.1 \\
\hline Adjusted R-squared & 0.607238 & S.D. dependent var & 359808.0 \\
\hline S.E. of regression & 225494.2 & Akaike info criterion & 27.67739 \\
\hline Sum squared resid & $5.59 \mathrm{E}+11$ & Schwarz criterion & 27.81433 \\
\hline Log likelihood & -190.7417 & L Hannan-Quinn criter. & 27.66471 \\
\hline F-statistic & 11.04948 & Durbin-Watson stat & 1.652187 \\
\hline Prob (F-statistic) & 0.002337 & & \\
\hline Source: Data output via E-views 9.0. & \multicolumn{4}{l}{}
\end{tabular}

Table-26. OLS Regression Result for FDI and IBKP.

\begin{tabular}{|c|c|c|c|c|}
\hline Variable & Coefficient & Std. Error & t-Statistic & Prob. \\
\hline $\mathrm{C}$ & 137623.3 & 125230.3 & 1.098962 & 0.2903 \\
\hline IBKP & 0.615405 & 0.228103 & 2.697929 & 0.0173 \\
\hline IBKP $(-2)$ & -0.186484 & 0.231791 & -0.804536 & 0.4345 \\
\hline R-squared & 0.618594 & \multicolumn{2}{|c|}{ Mean dependent var } & 644188.2 \\
\hline Adjusted R-squared & 0.564108 & \multicolumn{2}{|c|}{ S.D. dependent var } & 411463.2 \\
\hline S.E. of regression & 271656.9 & \multicolumn{2}{|c|}{ Akaike info criterion } & 28.02125 \\
\hline Sum squared resid & $1.03 \mathrm{E}+12$ & \multicolumn{2}{|c|}{ Schwarz criterion } & 28.16829 \\
\hline Log likelihood & -235.1806 & \multicolumn{2}{|c|}{ L Hannan-Quinn criter. } & 28.03587 \\
\hline F-statistic & 11.35315 & \multicolumn{2}{|c|}{ Durbin-Watson stat } & 1.131078 \\
\hline Prob (F-statistic) & 0.001174 & & & \\
\hline
\end{tabular}

Finally, Table 26 regression outcome reveals a positive and statistically significant relationship between foreign direct investments and international banking operations of the banking sector. Foreign direct investments would stand at $\$ 137,623.3$ million if the banking sector international banking operations is unbroken. Foreign direct investments will rise by 0.62 million if international banking operations rises by a unit. International banking operations significantly explained $56.41 \%$ variation in foreign direct investments by unarguable relying on the adjusted R-square value of 0.368425 . There is no autocorrelation in the 
estimation as this study vehemently relied on the serial correlation LM test in Table 3 for autocorrelation detection.

\subsection{Causal Relationship: Foreign Direct Investment and Banking Operations}

The casual significant relationship between foreign direct investments and banking operations was determined using the Granger causality test which ascertains the direction of relationship between variables of interest based on the default number of lag. Table 27 presents the output of the Granger Causality analysis. From Table 27, there is a significant two way causal/bidirectional relationship between foreign direct investments and total deposits of the banking sector. Causality flows from total deposits of banking sector to foreign direct investments and from foreign direct investments back to total deposit of banking sector at 5\% level of significance. This implies that total deposits of the banking sector has significant effect on foreign direct investments on one hand, while on the other hand, foreign direct investments also exerts significant effect on banking sector total deposits.

Table-27. Granger Causality Output for Foreign Direct Investment and Banking Operations.

\begin{tabular}{l|l|l|l|l}
\hline Null Hypothesis: & Obs & F-Statistic & Prob. & Remarks \\
\hline TDP does not Granger Cause FDI & 17 & 11.0533 & 0.0019 & Causality \\
FDI does not Granger Cause TDP & & 17.94618 & 0.0482 & Causality \\
\hline LAD does not Granger Cause FDI & & 0.60054 & 0.5642 & No Causality \\
FDI does not Granger Cause LAD & & 1.33750 & 0.2990 & No Causality \\
\hline FET does not Granger Cause FDI & 17 & 4.38318 & 0.0372 & Causality \\
FDI does not Granger Cause FET & & 3.42494 & 0.0069 & Causality \\
\hline DOMP does not Granger Cause FDI & 17 & 4.74806 & 0.0303 & Causality \\
FDI does not Granger Cause DOMP & & 2.65928 & 0.1107 & No Causality \\
\hline IBKP does not Granger Cause FDI & 17 & 0.89086 & 0.4358 & No Causality \\
FDI does not Granger Cause IBKP & & 3.27254 & 0.0734 & No Causality \\
\hline Source: Data output via E-views 9.0 .
\end{tabular}

Again, there is also bidirectional significant causal relationship between foreign exchange transactions of the banking sector and foreign direct investments in Nigeria. At 5\% level of significance, causality runs from foreign exchange transactions to foreign direct investments, and from foreign direct investments back to foreign exchange transactions. The disclosure from Table 27 is that foreign exchange transactions exerts significant influence on inflow of foreign direct investments in Nigeria, and at the same time, foreign direct investments significantly affects the banking sector foreign exchange transactions. Domiciliary operations of the banking sector was found to have significantly (at $5 \%$ level of significance) affected foreign direct investments as evidenced by the unidirectional causal relationship between foreign direct investment and domiciliary operations of the banking sector. Finally, international banking operations and loans and advances have no significant causal relationship with foreign direct investment in Nigeria. Causality does not flow/run from either direction at $5 \%$ level of significance.

\subsection{Discussion of Findings}

The positive significant relationship between foreign direct investments Table 22 and total deposit of the banking sector as well as the bidirectional causal relationship between total deposit of the banking sector and foreign direct investments Table 27 implies that total deposits of the banking sector fortifies foreign direct investment in Nigeria and foreign direct investment propels and increases deposits of the banking sector. Adeniyi, Omisakin, Egwaikhide and Oyinlola (2012) achieved the same result in Ghana, but Tajgardoon, Noormohamadi and Behname (2012) established the absent of a causal relationship between international banking operations and foreign direct investments in nine (9) countries from Organization Islamic Conference (OIC): Bahrain, Iran, Malaysia, United Arab Emirates, Pakistan, Kuwait, Saudi Arabia, Qatar and Turkey which is similar to the finding of this study as evidenced in Table 37. On the contrary, the positive and significant relationship between foreign direct investments and international banking operations would not affirm the result of Korna, Ajekwe and Idyu (2013) who envisaged that foreign direct investments and total assets of banks are negatively and significantly correlated. The international banking operations of the banking sector is a subsect of their total assets and as such, fit in the Korna, Ajekwe and Idyu (2013) research on foreign direct investments and total assets of banks. The long run relationship between foreign direct investment and loans and advances of the banking sector supports the works of Tsauran (2014) for Bostwana, Asante (2015) for Ghana and Adeniyi, Omisakin, Egwaikhide and Oyinlola (2012) for cross country analysis of Nigeria, Ghana and Gambia on one hand, but on the other hand, disagrees with Adeniyi, Omisakin, Egwaikhide and Oyinlola (2012) that loans and advances of the banking sector does not enhance foreign direct investments in selected countries in Africa. 


\section{Conclusion, Policy Implications and Contribution to Knowledge}

It is unarguably staunch that developing countries can attain a considerable height with respect to economic growth and development through the inflow of foreign direct investments which facilitates the transfer of technology, human capital and services among others. This study has vividly proved that the development of the financial system especially, the banking sector for an emerging economy like Nigeria will in no small measure spur inflow of foreign direct investments. This study does not in any way put to end further studies on the nexus between banking operations and foreign direct investments in the context of Nigeria, rather a driving force to broaden the horizon of studies with regard to banking operations and foreign direct investments in a bid to developing the financial system to attract more foreign direct investment and realizing the ambition of being among the top twenty (20) economies in the world even though not in 2020 that is very near, but in the nearest future.

From the findings emanating from this study, the following recommendations are offered for attention and consideration by policymakers to assuage development in the banking sector to attract more foreign direct investments in Nigeria.

1. To increase deposit base, the banking sector should adopt completely smart banking as this evidences low risk, reliability and stability of the banking sector which is essential for inflow of foreign direct investments. The inflow of foreign direct investment raises deposits in banks as foreign direct investment itself comes with fund in the host economy.

2. The Central Bank of Nigeria should cautiously focus on tackling monetary policy variables such monetary policy rate, cash reserve ratio, loan portfolio, etc. which a capable of attracting investors from abroad. A reduction in the monetary policy rate would possible results in low cost of capital thus attracting foreign directing investments which in turn increase the international banking operations of the banking sector. Frequent changes in the banking sector's reserve requirements and loan portfolio may shy away foreign investors.

3. The Central Bank of Nigeria should complement the fiscal policies of the federal government (government expenditure and fiscal deficit which lead to high money in circulation) with monetary policies in such a way as reduce inflation and exchange rate fluctuations among others. A lower inflation rate increases the purchasing power of money and a stable exchange rate enhances the foreign exchange transactions of the banking sector.

4. The government should make an ideal climate for foreign investors such as tax holidays and reduction in taxes. This gives room for foreign investors in the banking sector to have enough profit to expand operations thus increasing the domiciliary operations of the banking sector.

5. The foreign equity restriction to $10 \%$ for foreign participation in the banking sector in favour of indigenous investors should be looked into and raised to a range of say $20 \%-30 \%$. In period of boom, high equity participation in the banking sector will results to more capital inflows which in turn increases the credit the banking sector extends to the economy through loans and advances.

This study contributes to knowledge by explicitly ascertaining the causality between banking operations and foreign direct investments by using up-to-date data in the context of Nigeria. To the best of our knowledge based on the literature reviewed, this study is the first of its kind to succinctly determined the direction of causality between banking sector operations and foreign direction investments in Nigeria by utilizing the core banking sector operations indices: total deposits, loans and advances, foreign exchange transactions, domiciliary operations and international banking operations.

\section{References}

Adeniyi, O., Omisakin, O., Egwaikhide, F. O. \& Oyinlola, A. (2012). Foreign direct investment, economic growth and financial sector development in small open developing economies. Economic Analysis and Policy, 42(1): 105-127.

Ani, W. U., Odo, C. \& Okelue, U. D. (2012). Ownership structure reform and bank performance in Nigeria. Journal of Research in National Development, 1O(3): 334-344.

Asante, A. (2015). The impact of foreign direct investment on banking sector performance in Ghana, (Master's Thesis, Kwame Nkrumah University of Science and Technology, Ghana).

Desbordes, R. \& Wei, S. (2013). Foreign direct investment, financial development and the 2007-2010 global financial crisis. Department of Economics, Sir William Duncan Building, University of Strathclyde, 130 Rottenrow, Glasgow G4 oGE, Scotland, United Kingdom.

Goldberg, S. L. (2007). Financial sector FDI and host countries: New and old lessons. FRBNY Economic Policy Review, 3(1): 1-17.

Hope, N. C., Laurenceson, J. \& Qin, F. (2008). The impact of direct investment by foreign banks on China's banking industry. Stanford Centre for International Development, Working Paper No. 362.

Kim, E. (2013). Does a banking crisis reduce foreign direct investment? (Master's Thesis, Graduate School of Clemson University).

Korna, J. M., Ajekwe, T. \& Idyu, I. A. (2013). The impact of foreign direct investment on the Nigerian banking sector. Journal of Business and Management, 7(4): 77-92. 
Laifi, J. (2008). The determinants of foreign direct investment in banking sector: Does regional integration agreements matter? Centre de recherches économiques de Saint Etienne (CREUSET), 6 rue Basse des Rives 42023 Saint Etienne Cedex 2 France.

Louangrath, P. (2014). Foreign direct investment in the banking industry. Available from: https://www.researchgate.net/post/Which_are_the_relevant_FDI_theories_in_the_case_of_foreign bank_entry_into_host_countries.

Makoni, P. L. (2015). An extensive exploration of theories of foreign direct investment. Risk Governance and Control: Financial Markets and Institutions, 5(2): 77-83.

Manyo, S. T., Sabina, N. E. \& Ugochukwu, U. S. (2016). The effect of foreign exchange transaction on the performance of Nigerian banks. Journal of Business Management, 2(11): 139-154.

Ngerebo, T. A. (2012). The impact of foreign exchange fluctuation on the intermediation of banks in Nigeria (1970 - 2004). African Journal of Business Management, 6(11): 3872-3879.

O'Connor, A., Santos-Arteaga, F. J. and Tavana, M. (2013). A game-theoretical model of bank foreign direct investment strategy in emerging market economies. International Journal of Bank Marketing, 32(3): 194-222.

Oke, M. O. (2012). Foreign direct investment and the Nigerian financial sector growth. Asian Economic and Financial Review, 2(2): 262-275.

Onyekwena, C. (2012). Empirical investigation of the impact of foreign direct investment on manufacturing firms and banks in Nigeria, (Master's Thesis, University of Portsmouth, England).

Okeke, A. (2015). Nigerian banking and finance sector: Legal and regulatory overview. Available from: www.ajumogobiaokeke.com.

Poelhekke, S. (2014). Do global banks facilitate foreign direct investment? VU University Amsterdam and De Nederlandsche Bank (Dutch Central Bank).

Tsaurai, K. (2014). Banking sector development and foreign direct investment. A case of Botswana. Risk Governance and Control: Financial Markets and Institutions, 4(3): 44-50.

Tajgardoon, G., Noormohamadi, K. \& Behname, M. (2012). Foreign direct investment and Islamic banking: A granger causality test. Economics and Finance Review, 2(5): $08-13$.

Wezel, T. (2004). Foreign banks entry into emerging economies: An empirical assessment of the determinants and risk predicted on German FDI data. Studies of Economic Research Centre, Discussion Paper Series 01/2004. 